\title{
Erratum to: Editors' reply to P. K. Garg and B. K. Jain: "Conflict of interest: a long way ahead"
}

\author{
M. Pescatori · G. Gagliardi
}

Published online: 9 May 2012

(C) Springer-Verlag 2012

\section{Erratum to: Tech Coloproctol}

DOI 10.1007/s10151-012-0820-y

In the original publication, the article category was erroneously changed to Editorial in the production process. The correct category is Correspondence.

The online version of the original article can be found under doi: 10.1007/s10151-012-0820-y.

M. Pescatori

Rome, Italy

e-mail: ucpclub@virgilio.it

G. Gagliardi $(\square)$

New Orleans, LA, USA

e-mail: gagliarg@yahoo.com 